\title{
Amino acid sequence of the $\mathrm{Bb}$ fragment from human complement Factor $\mathrm{B}$
}

\author{
Alignment of the cyanogen bromide-cleavage peptides \\ Jean GAGNON and David L. CHRISTIE \\ M.R.C. Immunochemistry Unit, Department of Biochemistry, University of Oxford, South Parks Road, \\ Oxford OX1 3QU, U.K.
}

(Received 7 April 1982/Accepted 30 September 1982)

\begin{abstract}
The alignment of all the $\mathrm{CNBr}$-cleavage peptides of fragment $\mathrm{Bb}$ from human Factor $\mathrm{B}$ (a component of the alternative pathway of complement) was determined. This was derived from cleavage of the fragment $\mathrm{Bb}$ at arginine residues by using trypsin and clostripain. Details of the isolation and amino acid sequences of these peptides are given. Together with previously published $N$-terminal sequences of the $\mathrm{CNBr}$-cleavage peptides [Christie \& Gagnon (1982) Biochem. J. 201, 555-567], this provides the amino acid sequence of the $N$-terminal half of fragment $\mathrm{Bb}$.
\end{abstract}

Factor B is cleaved at a single Arg-Lys bond by Factor $\overline{\mathrm{D}}$ during the activation of complement. This results in an $N$-terminal $\mathrm{Ba}$ fragment and a $C$ terminal $\mathrm{Bb}$ fragment with molecular weights of approx. 30000 and 60000 respectively (Kerr, 1979; Lesavre et al., 1979; Niemann et al., 1980). The Bb fragment is the catalytically active component of the complex proteinases of the alternative pathway of complement, $\mathrm{C} 3$ convertase $\mathrm{C} \overline{\mathrm{Bb}}, \mathrm{Bb}$ and $\mathrm{C} 5$ convertase $\mathrm{C} \overline{\mathrm{3b}, \mathrm{Bb}, \mathrm{C} 3 \mathrm{~b}}$ (for reviews see Fothergill \& Anderson, 1978; Porter, 1979; Müller-Eberhard \& Schreiber, 1980; Reid \& Porter, 1981).

Partial amino acid sequence studies have showed Factor B to be a novel type of serine proteinase with a catalytic chain of approximately twice the size of proteinases previously studied (Christie et al., 1980; Mole \& Niemann, 1980). Although the $N$-terminal sequence of the $\mathrm{Bb}$ fragment showed no homology with the well-conserved $N$-termini of the activated forms of serine proteinases, considerable homology was found in the $C$-terminal portion of the molecule, which contained the essential active-site residues.

Details of the isolation and $N$-terminal sequences of nine $\mathrm{CNBr}$-cleavage peptides from Factor $\mathrm{B}$ have been reported (Christie \& Gagnon, 1982). These sequences accounted for 359 residues of Factor B and enabled full definition of the sequence containing the site of Factor $\bar{D}$ cleavage and the localization of a free thiol group in the $\mathrm{Bb}$ fragment. Since amino acid analyses of the $\mathrm{Ba}$ and $\mathrm{Bb}$ fragments indicated that all but one methionine

Abbreviations used: h.p.l.c., high-pressure liquid chromatography. The nomenclature of complement components is that recommended by the World Health Organisation (1968). residue are located within the $\mathrm{Bb}$ portion of the molecule, the alignment of the two $\mathrm{CNBr}$-cleavage peptides of the $\mathrm{Ba}$ fragment was deduced. Details of the isolation of the tryptic peptides and the alignment of the $\mathrm{CNBr}$-cleavage peptides of the $\mathrm{Bb}$ fragment are given in the present paper. The complete sequence of the large $C$-terminal $\mathrm{CNBr}$ cleavage peptide from Factor B, CB-II (molecular weight approx. 30000), is described in the following paper (Christie \& Gagnon, 1983). This work provides the complete sequence of 505 residues of the catalytically active $\mathrm{Bb}$ fragment of Factor $\mathrm{B}$.

\section{Materials and methods}

\section{Materials and general methods}

The materials used and procedures performed have been described previously (Christie \& Gagnon, 1982).

\section{Tryptic digest of the $B b$ fragment}

Reduced and $S-\left[{ }^{14} \mathrm{C}\right]$ carboxymethylated succinoylated $\mathrm{Bb}(890 \mathrm{nmol})$ in $0.1 \mathrm{M}-\mathrm{NH}_{4} \mathrm{HCO}_{3}$ $(10 \mathrm{ml})$ was incubated with Tos-Phe- $\mathrm{CH}_{2} \mathrm{Cl}$-treated trypsin $(0.28 \mathrm{mg})$ for $2 \mathrm{~h}$ at $37^{\circ} \mathrm{C}$. A further $0.28 \mathrm{mg}$ of enzyme was added, the incubation repeated and the digest freeze-dried. The digest was redissolved in $0.1 \mathrm{M}-\mathrm{NH}_{4} \mathrm{HCO}_{3}(1.5 \mathrm{ml})$ and centrifuged. The pellet was extracted with a further $1.5 \mathrm{ml}$ of $0.1 \mathrm{M}$ $\mathrm{NH}_{4} \mathrm{HCO}_{3}$, and the combined supernatants $(3 \mathrm{ml})$ were applied to a column of Sephadex G-50 (superfine grade) equilibrated with $0.1 \mathrm{M}-\mathrm{NH}_{4} \mathrm{HCO}_{3}$. The flow rate was $15 \mathrm{ml} / \mathrm{h}$, and $2.0 \mathrm{ml}$ fractions were collected. Peptides were detected by their absorbance at $280 \mathrm{~nm}$. The radioactivity of samples 
$(15 \mu \mathrm{l})$ from the column fractions was determined by scintillation counting. Peptides were further purified by ion-exchange chromatography on DEAESephacel and by h.p.l.c. as described in the Results section.

\section{Clostripain digest of the $B b$ fragment}

Unmodified $\mathrm{Bb}$ fragment $(10 \mathrm{mg}$ ) was subjected to limited proteolysis by incubation in $20 \mathrm{mM}$ $\mathrm{NH}_{4} \mathrm{HCO}_{3}(10 \mathrm{ml})$ with clostripain $(125 \mu \mathrm{g})$ for $2 \mathrm{~h}$ at $37^{\circ} \mathrm{C}$ and the digest freeze-dried. The digest was redissolved in $0.1 \mathrm{M}-\mathrm{NH}_{4} \mathrm{HCO}_{3}(2.0 \mathrm{ml})$ and applied to a column $(2 \mathrm{~cm} \times 90 \mathrm{~cm})$ of Sephadex G-75 equilibrated with $0.1 \mathrm{M}-\mathrm{NH}_{4} \mathrm{HCO}_{3}$. A fragment $\mathrm{Bb}, \mathrm{Cl}-3$, corresponding to the $\mathrm{N}$-terminal portion of $\mathrm{Bb}$ with a molecular weight of approx. 30000 , was eluted between 141 and $168 \mathrm{ml}$. The reduced and $S$ - $\left[{ }^{3} \mathrm{H}\right]$ carboxymethylated succinoylated fragment $\mathrm{Bb}, \mathrm{Cl}-3 \quad(2 \mathrm{mg})$ in $20 \mathrm{~mm}-\mathrm{NH}_{4} \mathrm{HCO}_{3}(1 \mathrm{ml})$ was further digested by incubation with clostripain $(25 \mu \mathrm{g})$ for $2 \mathrm{~h}$ at $37^{\circ} \mathrm{C}$. The digest was then subjected to gel filtration on a column $(2 \mathrm{~cm} \times 90 \mathrm{~cm})$ of Sephadex G-75 in $0.1 \mathrm{M}-\mathrm{NH}_{4} \mathrm{HCO}_{3}$. Peptides $\mathrm{Bb}, \mathrm{Cl}-3, \mathrm{Cl}-1$ and $\mathrm{Bb}, \mathrm{Cl}-3, \mathrm{Cl}-2$ were eluted at 142 $160 \mathrm{ml}$ and $162-192 \mathrm{ml}$ respectively. Peptides $\mathrm{Bb}, \mathrm{Cl}$ $3, \mathrm{Cl}-1$ and $\mathrm{Bb}, \mathrm{Cl}-3, \mathrm{Cl}-2$ from two such preparations were pooled before sequence analysis. Clostripain was activated immediately before use by incubation of the enzyme $(0.5 \mathrm{mg} / \mathrm{ml})$ in $20 \mathrm{mM}^{-}$ $\mathrm{NH}_{4} \mathrm{HCO}_{3} / 10 \mathrm{~mm}$-dithiothreitol, $\mathrm{pH} 8.0$, for $1 \mathrm{~h}$ at $37^{\circ} \mathrm{C}$.

\section{V8-proteinase digest of peptide $B b, T-1 e$}

Peptide Bb,T-1e $(80 \mathrm{nmol})$ was dissolved in $50 \mathrm{~mm}-\mathrm{NH}_{4} \mathrm{HCO}_{3} / 2 \mathrm{~mm}$-EDTA, pH $7.8(0.4 \mathrm{ml})$, and digested with $\mathrm{V} 8$ proteinase $(15 \mu \mathrm{g})$ for $4 \mathrm{~h}$ at $37^{\circ} \mathrm{C}$. The digest was injected on to a $\mu$-Bondapak $\mathrm{C}_{18}$ column equilibrated with $0.1 \% \quad \mathrm{NH}_{4} \mathrm{HCO}_{3} /$ acetonitrile $(95: 5, \mathrm{v} / \mathrm{v})$. A linear gradient of $60 \mathrm{~min}$ was pumped to the column at $1 \mathrm{ml} / \mathrm{min}$ to give a final solvent composition of $0.1 \% \quad \mathrm{NH}_{4} \mathrm{HCO}_{3}$ /acetonitrile $(60: 40, v / v)$. Peptides Bb, T-1e, SP-5 and $\mathrm{Bb}, \mathrm{T}-1 \mathrm{e}, \mathrm{SP}-14$ were eluted after 15 and $25 \mathrm{~min}$ respectively.

\section{V8-proteinase digest of peptide $\mathrm{Bb}, \mathrm{Cl}-3, \mathrm{Cl}-\mathrm{I}$}

Peptide $\mathrm{Bb}, \mathrm{Cl}-3, \mathrm{Cl}-1 \quad(40 \mathrm{nmol})$ in $50 \mathrm{~mm}^{-}$ $\mathrm{NH}_{4} \mathrm{HCO}_{3} / 2 \mathrm{~mm}$-EDTA, pH $7.8(0.5 \mathrm{ml})$, was digested with $\mathrm{V} 8$ proteinase $(7 \mu \mathrm{g})$ for $2 \mathrm{~h}$ at $37^{\circ} \mathrm{C}$. The digest was injected on to a Radial-pak $\mathrm{C}_{18}$ column (Waters Associates) equilibrated with $0.1 \%$ $\mathrm{NH}_{4} \mathrm{HCO}_{3}$ /acetonitrile $(95: 5, \mathrm{v} / \mathrm{v})$. A linear gradient of $60 \mathrm{~min}$ was applied to the column at $1 \mathrm{ml} / \mathrm{min}$ to give a final solvent composition of $0.1 \%$ $\mathrm{NH}_{4} \mathrm{HCO}_{3}$ /acetonitrole $(45: 55, \mathrm{v} / \mathrm{v})$. Two peaks, denoted SP-8 and SP-9, were eluted between 23 and $26 \mathrm{~min}$ from the time of injection. This material had identical amino acid compositions and these frac- tions were pooled before amino acid sequence analysis.

\section{V8-proteinase digest of peptide $C B-V$}

Peptide CB-V (approx. $100 \mathrm{nmol}$ ) in $50 \mathrm{~mm}$ $\mathrm{NH}_{4} \mathrm{HCO}_{3} / 2 \mathrm{~mm}$-EDTA, pH $7.8(0.5 \mathrm{ml})$, was digested with $\mathrm{V} 8$ proteinase $(25 \mu \mathrm{g})$ for $2 \mathrm{~h}$ at $37^{\circ} \mathrm{C}$. The digest was then subjected to h.p.l.c. as described above for the digest of peptide $\mathrm{Bb}, \mathrm{Cl}-3, \mathrm{Cl}-1$. Peptide CB-V,SP-14 was eluted $33 \mathrm{~min}$ from the time of injection.

\section{Results}

We have already reported details of the isolation and $N$-terminal sequences of the $\mathrm{CNBr}$-cleavage peptides from Factor B (Christie \& Gagnon, 1982). The present study showed that all but one methionine residue of Factor $\mathrm{B}$ were located in the $\mathrm{Bb}$ portion of the molecule. The succinoylated $\mathrm{Bb}$ fragment has now been subjected to digestion with trypsin to provide a complementary set of peptides necessary to the completion of the sequence of the $\mathrm{Bb}$ fragment. Automated sequence analysis of tryptic peptides and clostripain peptides containing methionine established the alignment of the $\mathrm{CNBr}$ cleavage peptides of the $\mathrm{Bb}$ fragment.

\section{Isolation of tryptic peptides from the succinoylated $B b$ fragment}

The tryptic digest of reduced and $S-\left[{ }^{14} \mathrm{C}\right]-$ carboxymethylated succinoylated $\mathrm{Bb}$ fragment was initially fractionated by gel filtration on a column $(2 \mathrm{~cm} \times 90 \mathrm{~cm})$ of Sephadex G-50 (superfine grade) equilibrated with $0.1 \mathrm{M}-\mathrm{NH}_{4} \mathrm{HCO}_{3}$ (Fig. 1a). Fractions were pooled as indicated and designated T-1-T-6, and freeze-dried.

Isolation and amino acid composition of peptides from the T-1 pool (Fig. 1a)

The tryptic peptides present in pool $\mathrm{T}$-1 were further purified by ion-exchange chromatography on a column $(1 \mathrm{~cm} \times 25 \mathrm{~cm})$ of DEAE-Sephacel, equilibrated with $0.25 \mathrm{M}-\mathrm{NH}_{4} \mathrm{HCO}_{3}$ and developed with a linear gradient of $\mathrm{NH}_{4} \mathrm{HCO}_{3}(0.25-1.0 \mathrm{M})$ in a total volume of $300 \mathrm{ml}$ (Fig. 1 b). Nine pools were made as indicated and designated DE-1-DE-9. Five peptides were subsequently isolated from these pools, and these peptides were designated T-1a-T-1e. Amino acid analysis indicated that pools DE-1 and DE-2 contained the same peptide (T-1a), and no further purification was performed. Peptides from other fractions were purified further by h.p.l.c. on a $\mu$-Bondapak $\mathrm{C}_{18}$ column $(3.9 \mathrm{~mm} \times 300 \mathrm{~mm})$ equilibrated with $0.1 \% \quad \mathrm{NH}_{4} \mathrm{HCO}_{3} /$ acetonitrile $(90: 10$, $\mathrm{v} / \mathrm{v})$. A linear gradient of $30 \mathrm{~min}$ was pumped to the column at $1 \mathrm{ml} / \mathrm{min}$ to give a final solvent composition of $0.1 \% \mathrm{NH}_{4} \mathrm{HCO}_{3} /$ acetonitrile $(70: 30, \mathrm{v} / \mathrm{v})$. 

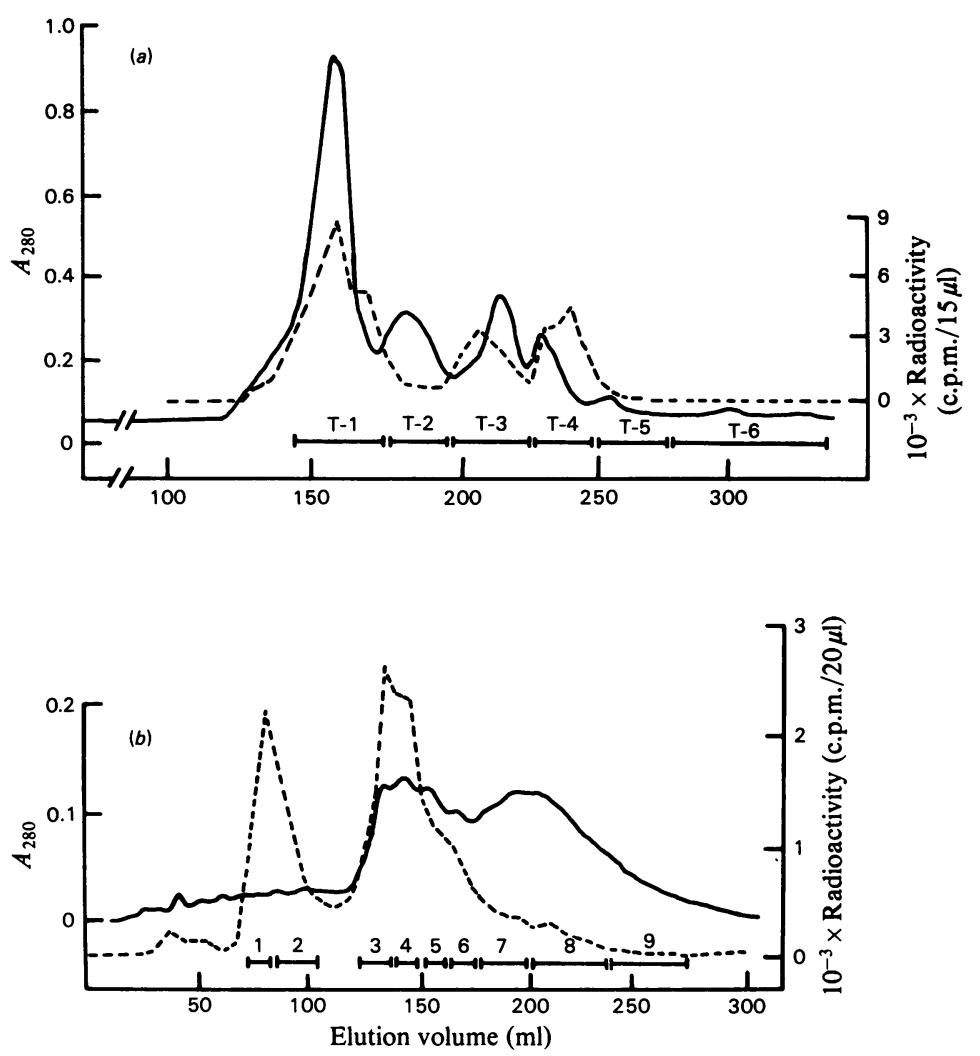

Fig. 1. Separation of the peptides from the tryptic digest of the succinoylated Bb fragment

(a) The freeze-dried digest was dissolved in $0.1 \mathrm{M}-\mathrm{NH}_{4} \mathrm{HCO}_{3}(3 \mathrm{ml})$ and applied to a column $(2 \mathrm{~cm} \times 90 \mathrm{~cm})$ of Sephadex G-50 (superfine grade) equilibrated with $0.1 \mathrm{M}-\mathrm{NH}_{4} \mathrm{HCO}_{3}$. The flow rate was $15 \mathrm{ml} / \mathrm{h}$, and $2 \mathrm{ml}$ fractions were collected. The radioactivity present in portions $(15 \mu \mathrm{l})$ of column fractions was determined by scintillation counting. Fractions were pooled as indicated, designated T-1-T-6 and freeze-dried.,$- A_{280}$; --- , radioactivity. (b) The freeze-dried material corresponding to pool T-1 above was redissolved in $0.25 \mathrm{M}-\mathrm{NH}_{4} \mathrm{HCO}_{3}(3 \mathrm{ml})$, and applied to a column $(1 \mathrm{~cm} \times 25 \mathrm{~cm})$ of DEAE-Sephacel equilibrated with the same buffer and developed with a linear gradient of $\mathrm{NH}_{4} \mathrm{HCO}_{3}(0.25-1.0 \mathrm{M})$ in a total volume of $3000 \mathrm{ml}$ at a flow rate of $12 \mathrm{ml} / \mathrm{h}$. Portions $(20 \mu \mathrm{l})$ of column fractions $(2.5 \mathrm{ml})$ were taken for counting of radioactivity. Nine pools were made and designated in order of their elution DE-1-DE-9.,$- A_{280}$; ----, radioactivity.

Two peptides (T-1b and T-1c) were isolated from pools DE-3-DE-5 by this procedure. Similarly, a further two peptides (T-1d and T-1e) were isolated from pools DE-7 and DE-8. Peptides were not isolated from pools DE-6 and DE-9 in an acceptable yield.

Three of the five peptides isolated from the T-1 pool of the tryptic digest of succinoylated fragment $\mathrm{Bb}$ were found to contain methionine. The amino acid compositions of two of these, peptides T-1c and $\mathrm{T}$-1e, are presented in Table 1 . The third methioninecontaining peptide (T-1d), isolated in only a $12 \%$ yield, was found on further analysis to be derived partly from a chymotryptic-like cleavage (see below). Yields of peptides T-1a and T-1b and their positions in the sequence of fragment $\mathrm{Bb}$ estimated from their amino acid compositions are presented in Table 2.

Isolation and amino acid compositions of the peptides from pools T-2-T-6 of the tryptic digest of succinoylated fragment $\mathrm{Bb}$ (Fig. 1a)

Peptides from pools T-2-T-6 of the tryptic digest of fragment $\mathrm{Bb}$ were purified directly by h.p.l.c. Water $(0.9 \mathrm{ml})$ and $10 \%(\mathrm{v} / \mathrm{v})$ trifluoroacetic acid $(0.1 \mathrm{ml})$ was added to the freeze-dried material, and a portion $(0.3 \mathrm{ml})$ was centrifuged. The soluble material was injected on to a $\mu$-Bondapak $C_{18}$ column equilibrated with $0.1 \%$ trifluoroacetic acid/ solvent B $(95: 5, \mathrm{v} / \mathrm{v})$; solvent B was methanol/ acetonitrile/propan-2-ol (1:1:1, by vol.). A linear gradient of $45 \mathrm{~min}$ was applied to the column at 
Table 1. Amino acid compositions and details of automated Edman degradation of peptides used to complete the alignment of the CNBr-cleavage peptides of fragment $B b$

Compositions are given as mol of residues/mol of peptide and were calculated from $24 \mathrm{~h}$-hydrolysis values. Values less than 0.2 have been omitted. Values for any particular peptide are normalized with respect to the residue marked with an asterisk $\left(^{*}\right)$. Cysteine was determined as $S$-carboxymethylcysteine. For peptide CB-V,SP-14, methionine was determined as homoserine. Abbreviation: N.D., not determined.

Amino acid compositions ( $\mathrm{mol}$ of residue/mol)

\begin{tabular}{|c|c|c|c|c|c|c|c|}
\hline Peptide $\ldots$ B & $\mathrm{Bb}, \mathrm{T}-1 \mathrm{c}$ & $\mathrm{Bb}, \mathrm{T}-3-7 \mathrm{~b} / 8 \mathrm{~b}$ & $\mathrm{Bb}, \mathrm{T}-1 \mathrm{e}$ & $\mathrm{Bb}, \mathrm{T}-1 \mathrm{e}, \mathrm{SP}-5$ & $\mathrm{Bb}, \mathrm{T}-1 \mathrm{e}, \mathrm{SP}-14$ & $\mathrm{Bb}, \mathrm{Cl}-3, \mathrm{Cl}-1, \mathrm{SP}-8 / 9$ & $\mathrm{Bb}, \mathrm{Cl}-3, \mathrm{Cl}-2$ \\
\hline Asx & 4.6 & 4.2 & 10.2 & 2.0 & 0.9 & 5.0 & 11.8 \\
\hline Thr & 2.7 & 1.8 & 0.4 & - & 0.5 & 1.7 & 1.2 \\
\hline Ser & 4.6 & - & 3.2 & - & 1.9 & 2.9 & 5.3 \\
\hline Glx & 7.2 & 1.3 & 9.4 & $2.0^{*}$ & $2.0^{*}$ & $2.0^{*}$ & 7.8 \\
\hline Pro & 1.4 & 1.1 & 1.0 & - & - & 2.3 & 3.1 \\
\hline Gly & 5.1 & 3.2 & 3.3 & - & 1.2 & 2.6 & 4.8 \\
\hline Ala & 4.3 & - & 2.5 & - & - & 2.0 & 3.5 \\
\hline Cys & 2.1 & - & 1.0 & - & 0.5 & - & 1.2 \\
\hline Val & 7.1 & 2.2 & 8.8 & 1.0 & 1.1 & 2.9 & 9.0 \\
\hline Met & 1.2 & 1.7 & 2.4 & 0.8 & 0.5 & 0.9 & 2.1 \\
\hline Ile & 3.1 & 4.4 & 2.0 & 0.8 & - & 0.9 & 3.3 \\
\hline Leu & 2.0 & 2.2 & 6.1 & - & 1.7 & 2.4 & 6.8 \\
\hline Tyr & 2.4 & - & 3.2 & 0.8 & - & 1.0 & 3.3 \\
\hline Phe & 2.1 & - & 2.7 & 0.8 & - & - & 2.4 \\
\hline His & 3.7 & 1.9 & 1.9 & - & - & 0.8 & $1.0^{*}$ \\
\hline Lys & 7.1 & - & 4.3 & - & 0.5 & 3.5 & 7.1 \\
\hline Arg & $2.0^{*}$ & $1.0^{*}$ & $1.0^{*}$ & - & 0.5 & 0.8 & 1.5 \\
\hline Total residues & 63 & 25 & 64 & 9 & 12 & 32 & 75 \\
\hline Yield of peptide (\%) & 30 & 37 & 22 & 18 & 5 & 11 & 45 \\
\hline $\begin{array}{l}\text { Amount used in auto- } \\
\text { mated sequence } \\
\text { analysis (nmol) }\end{array}$ & 110 & 120 & 118 & 60 & 15 & 15 & 90 \\
\hline Initial yield (\%) & 68 & 55 & 42 & 68 & 47 & 75 & 38 \\
\hline Repetitive yield (\%) & 92 & 90 & N.D. & 91 & 88 & 92 & 95 \\
\hline
\end{tabular}

Table 2. Yields of tryptic peptides from reduced and carboxymethylated succinoylated fragment $B b$, and their positions in the sequence

\begin{tabular}{lcc} 
Peptide & Yield (\%) & Position in sequence \\
T-1a & 79 & $350-383$ \\
T-1b & 50 & $288-346$ \\
T-1c & 30 & $227-287$ \\
T-1d & 12 & $50-120$ \\
T-1e & 22 & $161-226$ \\
T-3-3a/4a & 53 & $384-399$ \\
T-3-10a/11a & 46 & $400-420$ \\
T-3-7b/8b & 37 & $123-147$ \\
T-3-9b & 54 & $481-505$ \\
T-4-3a/T-5-6a & 32 & $438-449$ \\
T-4-4a/5a & 34 & $421-437$ \\
T-4-11b/14b & 49 & $452-471$ \\
T-5-2a/T-6-3a & 53 & $157-160$ \\
T-5-3a/4a/5a & 68 & $472-480$ \\
T-5-8a/3b & 88 & $148-156$ \\
T-6-1a/2a & 49 & $450-451,121-122$ \\
T-6-4a & 33 & $347-349$ \\
\hline
\end{tabular}

$1 \mathrm{ml} / \mathrm{min}$ to give a final solvent composition of $0.1 \%$ trifluoroacetic acid/solvent B $(45: 55, \mathrm{v} / \mathrm{v})$.

The acid-insoluble material present in the pellets obtained by centrifugation was recovered by freeze- drying, and subsequently dissolved in $0.1 \%$ $\mathrm{NH}_{4} \mathrm{HCO}_{3}$ and injected on to a $\mu$-Bondapak $\mathrm{C}_{18}$ column equilibrated with $0.1 \% \quad \mathrm{NH}_{4} \mathrm{HCO}_{3}$ /acetonitrile $(95: 5, \mathrm{v} / \mathrm{v})$. A linear gradient of $60 \mathrm{~min}$ was applied to a column at $1 \mathrm{ml} / \mathrm{min}$ to give a final solvent composition of $0.1 \% \quad \mathrm{NH}_{4} \mathrm{HCO}_{3}$ /acetonitrile $(45: 55, \mathrm{v} / \mathrm{v})$. One glycopeptide, apparently derived from a chymotryptic-like cleavage, was isolated from pool T-2. Its amino acid composition $\left(\right.$ Asp $\left._{3}, \mathrm{Ser}_{1}, \mathrm{Glu}_{1}, \mathrm{Pro}_{3}, \mathrm{Gly}_{1}, \mathrm{Val}_{1}, \mathrm{Arg}_{1}\right)$ corresponded to positions 108-120 of the sequence.

Yields of the tryptic peptides isolated from pools T-3-T-6 of the tryptic digest of succinoylated fragment $\mathrm{Bb}$ (Fig. 1a) and their estimated position in the sequence are presented in Table 2. Peptides isolated by h.p.l.c. in trifluoroacetic acid- or $\mathrm{NH}_{4} \mathrm{HCO}_{3}$-based solvent systems are denoted 'a' or 'b' respectively. Peptides isolated from the same h.p.l.c. run were numbered sequentially according to their order of elution. As indicated by Table 2, some peptides were present in more than one pool after gel filtration of the tryptic digest on Sephadex G-50 (Fig. 1a). Adjacent fractions from h.p.l.c. fractions frequently contained peptides of identical amino acid composition. This is attributed to the partial deamid- 
ation or other uncharacterized differences resulting in differential mobility. In these cases, fractions containing peptides of identical amino acid composition were pooled as indicated in Table 2. Only peptide $\mathrm{Bb}, \mathrm{T}-3-7 \mathrm{~b} / 8 \mathrm{~b}$ from pools $\mathrm{T}-2-\mathrm{T}-6$ contained methionine, as indicated by its amino acid composition.

\section{Alignment of the CNBr-cleavage peptides from the $B b$ fragment}

We have previously aligned the $\mathrm{CNBr}$-cleavage peptides CB-VII-3 and CB-IV at the $N$-terminus and peptide CB-II at the $C$-terminus of the $\mathrm{Bb}$ fragment (Christie et al., 1980; Christie \& Gagnon, 1982). The alignment of all the $\mathrm{CNBr}$-cleavage peptides has now been established after isolation and sequencing of peptides derived from cleavage of the $\mathrm{Bb}$ fragment with trypsin and clostripain (Fig. 2).

Automated sequence analysis of peptides containing methionine from the tryptic digest of succinoylated fragment $B b$

Four peptides $\mathrm{Bb}, \mathrm{T}-1 \mathrm{c}, \mathrm{Bb}, \mathrm{T}-1 \mathrm{~d}, \mathrm{Bb}, \mathrm{T}-1 \mathrm{e}$ and $\mathrm{Bb}, \mathrm{T}-3-7 \mathrm{~b} / 8 \mathrm{~b}$ from the tryptic digest of succinoylated fragment $\mathrm{Bb}$ were found to contain methionine (Tables 1 and 2).

Peptide $B b, T$-1c. The $N$-terminal 41 residues of peptide Bb,T-1c were established by automated Edman degradation (Fig. 2 and Table 1). The sequence corresponding to residues $227-268$ of the $\mathrm{Bb}$ fragment provides an overlap between the $C$-terminal sequence of peptide CB-VIa and the $N$-terminal sequence of peptide CB-II, aligning these two peptides in the order:

\section{CB-VIa-CB-II}

This confirms the results of previous work from the sequence of a clostripain-digest fragment (Christie $e t$ al., 1980).

Peptide $B b, T-3-7 b / 8 b$. Automated sequence analysis enabled identification of 24 of the 25 residues of this peptide (Fig. 2 and Table 1). The sequence overlaps with the $C$-terminal sequence of the $\mathrm{CNBr}$-cleavage peptide $\mathrm{CB}-\mathrm{VIb}$, which has previously been shown to contain 2 mol of homoserine $/ \mathrm{mol}$, indicating the presence of a methionyl bond resistant to CNBr (Christie \& Gagnon, 1982). The sequence of peptide $\mathrm{Bb}, \mathrm{T}-3-7 \mathrm{~b} / 8 \mathrm{~b}$ revealed the presence of a Met-Thr bond and the sequence of a peptide Thr-Asp-Gly-Leu-His-Asn-Met that had not been isolated from $\mathrm{CNBr}$ digests of the $\mathrm{Bb}$ fragment. The sequence of peptide $B b, T-3-7 b / 8 b$ overlapped with the $N$-terminal sequence of the $\mathrm{CNBr}$ cleavage peptide CB-V. This aligns peptides CB-VIb and $\mathrm{CB}-\mathrm{V}$ in the order:

\section{CB-VIb-CB-V}

Peptide $B b, T-1 e$. This peptide contained approx. $3 \mathrm{~mol}$ of methionine/mol (Table 1), and automated sequence analysis showed it to result from cleavage of the Arg-Glu bond at position 160 of the $\mathrm{Bb}$ fragment (Fig. 2). Difficulty was encountered in sequencing this peptide, despite a good initial coupling yield and a single sequence Glu-Asp-being obtained from the first two cycles (Fig. 2 and Table 1). The tyrosine residue at position 3 of peptide $\mathrm{Bb}, \mathrm{T}-\mathrm{e}$, corresponding to position 163 of fragment $\mathrm{Bb}$, reacted only partially with phenyl isothiocyanate (approx. 35\%) under the conditions of the usual sequence programme. A further $28 \%$ reacted during cycle no. 4 , with the result that both leucine and tyrosine were identified at this position. The poor reaction of the tyrosine residue may be a consequence of the succinoylation procedure, as no such difficulties were encountered during sequence analysis of the unmodified $\mathrm{CNBr}$-cleavage peptide CB-V. Similar problems were not, however, encountered with other peptides after succinoylation. Despite the difficulties resulting from overlapping repetitive sequences, it was possible to assign tentatively residues to the sequence of peptide $\mathrm{Bb}, \mathrm{T}-1 \mathrm{e}$, to extend the sequence of peptide CB-V and align this peptide with the $\mathrm{CNBr}$-cleavage peptide CB-VII-2 in the order:

\section{CB-V-CB-VII-2}

To overcome the difficulties encountered in sequencing peptide $\mathrm{Bb}, \mathrm{T}-1 \mathrm{e}$, the remaining amount of peptide $(80 \mathrm{nmol})$ was digested with V8 proteinase, and the peptides were isolated by h.p.l.c. as described in the Materials and methods section. Two peptides were found to contain methionine, namely $\mathrm{Bb}, \mathrm{T}-1 \mathrm{e}, \mathrm{SP}-5$ and $\mathrm{Bb}, \mathrm{T}-1 \mathrm{e}, \mathrm{SP}-14$.

The entire sequence of nine residues of peptide $\mathrm{Bb}, \mathrm{T}-1 \mathrm{e}, \mathrm{SP}-5$, corresponding to positions 204-212 of fragment $\mathrm{Bb}$, was determined by automated sequence analysis (Fig. 2 and Table 1). The $C$-terminal sequence of this peptide provided an overlap of three residues with the $N$-terminal sequence of peptide CB-VII-1. This provided the alignment of peptides CB-VII-2 and CB-VII-1 in the order:

\section{CB-VII-2-CB-VII-1}

The entire sequence of 12 residues of peptide Bb,T-1e,SP-14, corresponding to positions 213-224 of fragment $\mathrm{Bb}$, were determined by automated sequence analysis (Fig. 2 and Table 1). The amino acid composition of this peptide indicates that it is contaminated, although only a single sequence was obtained. The $C$-terminal sequence of this peptide overlapped by three residues with the $N$-terminal sequence of peptide CB-VIa, giving the alignment of CNBr-cleavage peptides CB-VII-1 and CB-VIa in the order:

\section{CB-VII-1-CB-VIa}

A third peptide containing methionine, which would 


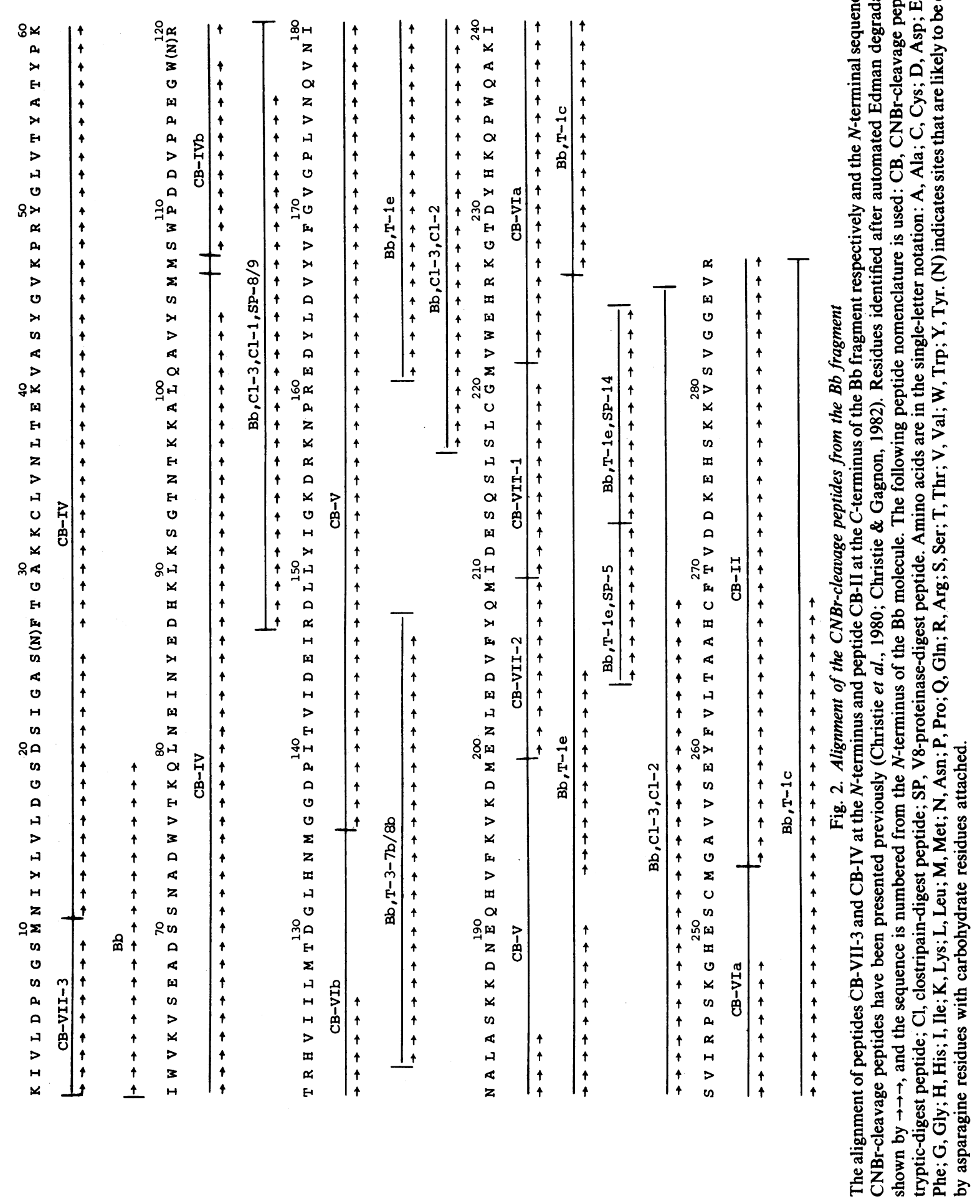


have provided an overlap between the $C$-terminal sequence of CB-V and CB-VII-2, was not recovered from the V8-proteinase digest of peptide $\mathrm{Bb}, \mathrm{T}-1 \mathrm{e}$.

The sequence of a peptide $\mathrm{Bb}, \mathrm{T}-1 \mathrm{e}, \mathrm{SP}-21$ confirmed the sequence of residues 161-190 (Fig. 2) of the $\mathrm{Bb}$ fragment (results not shown).

Peptide Bb,T-1d. A major sequence Ala-ThrTyr-Pro-Lys- and a minor sequence corresponding to Tyr-Gly-Leu-Val-Thr-Tyr-Ala-Thr-Tyr- was obtained when peptide $\mathrm{Bb}, \mathrm{T}-1 \mathrm{~d}$ was subjected to automated sequence analysis. This heterogeneity indicates that most of the peptide was derived from a chymotryptic-like cleavage of a Tyr-Ala bond at position 55 of the $\mathrm{Bb}$ fragment. The minor sequence represents the expected peptide from cleavage of the Arg-Tyr bond at position 49 of the $\mathrm{Bb}$ fragment. Peptide Bb,T-1d was subjected to digestion with V8 proteinase, and the peptides were isolated by h.p.l.c. as described for peptide Bb,T-1e. A peptide containing methionine was isolated, although the sequence could not be extended beyond Tyr-104 from the previously established sequence of CB-IV (results not shown).
Isolation and sequence of peptides $\mathrm{Bb}, \mathrm{Cl}-3-\mathrm{Cl}-\mathrm{I}$ and $\mathrm{Bb}, \mathrm{Cl}-3, \mathrm{Cl}-2$ generated from the $\mathrm{Bb}$ fragment by proteolysis with clostripain

Proteolysis of the $\mathrm{Bb}$ fragment by clostripain results in an $N$-terminal fragment $\mathrm{Bb}, \mathrm{Cl}-3$ with a molecular weight of 30000 (Christie \& Gagnon, 1982). This peptide can be isolated by gel filtration on Sephadex G-75 (Fig. 3a), and from its amino acid composition it contains approx. $8 \mathrm{~mol}$ of methionine and $7 \mathrm{~mol}$ of arginine $/ \mathrm{mol}$. The peptide $\mathrm{Bb}, \mathrm{Cl}-3$ was thus a convenient starting material from which to isolate the remaining peptides required to complete the alignment of the $\mathrm{CNBr}$-cleavage peptides of the $\mathrm{Bb}$ fragment. The strategy was still dependent on cleavage at arginine residues, although in this case clostripain was used to digest the $\mathrm{Bb}, \mathrm{Cl}-3$ fragment further with avoidance of difficulties encountered with trypsin owing to some chymotryptic-like activity (i.e. peptide $\mathrm{Bb}, \mathrm{T}-1 \mathrm{~d}$ ). The $\mathrm{Bb}, \mathrm{Cl}-3$ fragment was fully reduced and alkylated and succinoylated to minimize the possibility of cleavage at lysine residues and render the fragment susceptible to
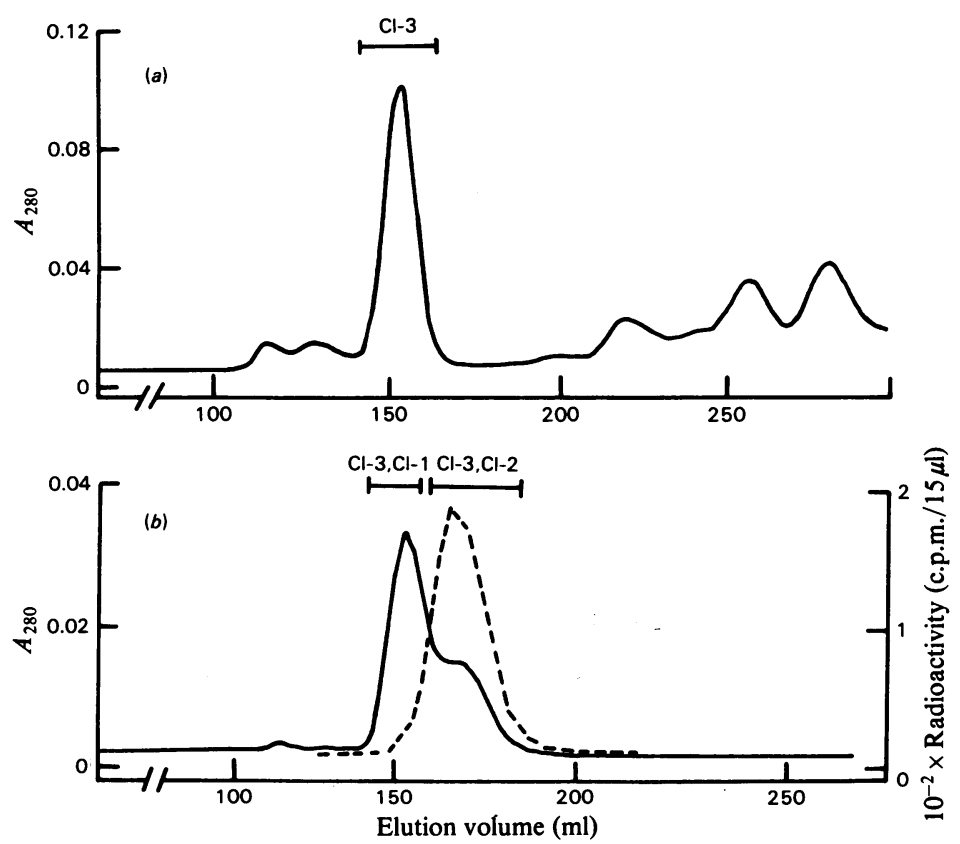

Fig. 3. Separation of the peptides from the clostripain digest of the $B b$ fragment

(a) The freeze-dried clostripain digest of the $\mathrm{Bb}$ fragment $(10 \mathrm{mg})$ was dissolved in $0.1 \mathrm{M}-\mathrm{NH}_{4} \mathrm{HCO}_{3}(2.0 \mathrm{ml})$ and applied to a column $(2 \mathrm{~cm} \times 90 \mathrm{~cm})$ of Sephadex G-75 equilibrated with $0.1 \mathrm{M}-\mathrm{NH}_{4} \mathrm{HCO}_{3}$. The flow rate was $10 \mathrm{ml} / \mathrm{h}$, and $2.5 \mathrm{ml}$ fractions were collected. The peptide $\mathrm{Bb}, \mathrm{Cl}-3$ was pooled as indicated and freeze-dried.,$- A_{280} \cdot(b)$ Reduced and $S$-carboxymethylated succinoylated peptide $\mathrm{Bb}, \mathrm{Cl}-3$ was further digested with clostripain and subjected to gel filtration as described for $(a)$. Portions $(15 \mu \mathrm{l})$ of column fractions $(2 \mathrm{ml})$ were taken for counting of radioactivity. Peptide $\mathrm{Bb}, \mathrm{Cl}-3, \mathrm{Cl}-1$ and peptide $\mathrm{Bb}, \mathrm{Cl}-3, \mathrm{Cl}-2$ were pooled as indicated.,$- A_{280}$; $-{ }^{--}$, radioactivity. 
further cleavage by clostripain. Two main fragments were isolated by gel filtration of the clostripain digest of $\mathrm{Bb}, \mathrm{Cl}-3$ fragment on Sephadex G-75 (Fig. $3 b$ ). The peptides $\mathrm{Bb}, \mathrm{Cl}-3, \mathrm{Cl}-1$ and $\mathrm{Bb}, \mathrm{Cl}-$ 3, $\mathrm{Cl}-2$ were pooled as indicated. Both peptides were found to contain methionine and each was about 70 residues long. The amino acid analysis of peptide $\mathrm{Bb}, \mathrm{Cl}-3, \mathrm{Cl}-1$ showed it to contain carbohydrate, although the amount of glucosamine was not quantified. The presence of carbohydrate accounts for the separation of the two peptides on Sephadex G-75.

A small amount (approx. $5 \mathrm{nmol}$ ) of each of the peptides $\mathrm{Bb}, \mathrm{Cl}-3, \mathrm{Cl}-1$ and $\mathrm{Bb}, \mathrm{Cl}-3, \mathrm{Cl}-2$ were subjec- camine, and automated Edman degradation was resumed. This enabled the identification of the $N$-terminal 47 residues of peptide $\mathrm{Bb}, \mathrm{Cl}-3, \mathrm{Cl}-2$ (Fig. 2 and Table 3). This completes the sequence of peptide CB-V and provides an overlap with the $N$-terminal sequence of peptide CB-VII-2, corresponding to residues 161-207 of the $\mathrm{Bb}$ fragment. The sequence of residues 191-199 of the $\mathrm{Bb}$ fragment (Fig. 2) was confirmed by the sequence of a peptide CB-V,SP-14 isolated from a V8-proteinase digest of peptide CB-V (results not shown). The sequence of peptide $\mathrm{Bb}, \mathrm{Cl}-3, \mathrm{Cl}-2$ completes the alignment of all of the $\mathrm{CNBr}$-cleavage peptides of the $\mathrm{Bb}$ fragment in the order:

CB-VII-3-CB-IV-CB-VIb-CB-V-CB-VII-2-CB-VII-1-CB-VIa-CB-II

ted to $N$-terminal sequence analysis, which showed the peptides to be derived from cleavage of the arginine residues at positions 49 and 156 of the $\mathrm{Bb}$ fragment respectively.

Peptide $\mathrm{Bb}, \mathrm{Cl}-3, \mathrm{Cl}-1$. This peptide was digested with V8 proteinase, and the peptides were isolated as described in the Materials and methods section. Fractions SP-8 and SP-9 contained peptides of identical amino acid composition, and these were pooled before sequence analysis. From the amino acid composition, peptide $\mathrm{Bb}, \mathrm{Cl}-3, \mathrm{Cl}-1, \mathrm{SP}-8 / 9$ contains $2 \mathrm{~mol}$ of methionine $/ \mathrm{mol}$ (Table 1). The $N$-terminal 30 residues of this peptide showed it to result from cleavage of a Glu-Asp bond at position 86 of the $\mathrm{Bb}$ fragment (Fig. 2 and Table 1). This sequence extended the sequence of peptide CB-IV and provided an overlap with the sequence of peptide CB-VIb, aligning these two peptides in the order:

\section{CB-IV-CB-VIb}

The sequence of peptide $\mathrm{Bb}, \mathrm{Cl}-3, \mathrm{Cl}-1, \mathrm{SP}-8 / 9$ revealed a -Ser-Met-Met-Ser- sequence after position 104 , and thus an additional methionine residue between the $\mathrm{CNBr}$-cleavage peptide $\mathrm{CB}$-IV and $\mathrm{CB}-\mathrm{VIb}$. The sequence of peptide $\mathrm{Bb}, \mathrm{Cl}-3, \mathrm{Cl}-1, \mathrm{SP}$ $8 / 9$ does not totally agree with the results of amino acid analysis, which are notably high in valine and low in methionine. Despite this, a single sequence was obtained during automated Edman degradation.

Peptide $\mathrm{Bb}, \mathrm{Cl}-3, \mathrm{Cl}-2$. Similar difficulties to those described for peptide $\mathrm{Bb}, \mathrm{T}-\mathrm{le}$ were encountered during sequence analysis of peptide $\mathrm{Bb}, \mathrm{Cl}-3, \mathrm{Cl}-2$ owing to the inefficient coupling of the tyrosine at position 163 of the sequence of fragment $\mathrm{Bb}$. In this case, however, the sequencer was stopped after 16 cycles of Edman degradation, when proline was the $N$-terminal residue of the main sequence. The other sequences were blocked by the addition of fluores-
This work also provides the complete sequence of all but the large $C$-terminal $\mathrm{CNBr}$-cleavage peptide CB-II, which comprises residues $1-253$ of the $\mathrm{Bb}$ fragment (Fig. 2).

\section{Discussion}

In this paper we have presented details of the isolation and amino acid sequences of peptides derived from cleavage of the $\mathrm{Bb}$ fragment at arginine residues. This has enabled the alignment of all the $\mathrm{CNBr}$-cleavage peptides from the $\mathrm{Bb}$ fragment, and completes the sequence of all but one of these peptides, accounting for the $N$-terminal 253 residues of the $\mathrm{Bb}$ fragment. The sequence of the $C$-terminal $\mathrm{CNBr}$-cleavage peptide $\mathrm{CB}$-II and the complete sequence of the $\mathrm{Bb}$ fragment is presented in the following paper (Christie \& Gagnon, 1983).

A total of 18 peptides were isolated from a tryptic digest of succinoylated fragment $\mathrm{Bb}$, by using a combination of gel filtration, ion-exchange and h.p.l.c., in yields ranging from 12 to $88 \%$ (Tables 1 and 2). It should be noted that fraction $T-6-1 a / 2 a$ contains two peptides of sequence Ser-Arg and Thr-Arg. The peptide corresponding to residues $1-49$ of the $\mathrm{Bb}$ fragment was not isolated from the digest, although it is probable that that peptide was eluted from the Sephadex G-50 column immediately before the T-1 pool (Fig. 1a). No attempt was made to recover this peptide, which would have a blocked $N$-terminal residue. From the complete sequence of the $\mathrm{Bb}$ fragment in the following paper (Christie \& Gagnon, 1983) it can be seen that fragment $\mathrm{Bb}$ contains 20 arginine residues/molecule. Allowing for the presence of two resistant Arg-Pro bonds at positions 244 and 334 of the sequence, a total of 19 tryptic peptides would have been expected, which is in complete agreement with our results.

Three of the four tryptic peptides containing methionine are present in the T-1 pool (mol.wt. 
approx 6000). The similar size and charge of these peptides required a more complicated purification procedure than would normally be expected. Ionexchange chromatography (Fig. $1 b$ ) provided a partial separation, although h.p.l.c. was required as a final step. H.p.l.c. alone was not sufficient to purify these peptides.

In addition to difficulties in isolating the methionine-containing peptides from the T-1 pool, problems were also encountered during $N$-terminal sequence analysis. Extended sequence analysis of peptide $\mathrm{Bb}, \mathrm{T}-\mathrm{le}$ was not possible owing to the inefficient coupling of the tyrosine residue corresponding to position 163 of the sequence of fragment $\mathrm{Bb}$. We have not experienced such difficulties with other succinoylated tryptic peptides, nor have we seen such troubles reported in the literature. The poor reactivity of the tyrosine residue may well result from the conformation of this peptide, particularly after the introduction of negatively charged groups on the lysine residues.

The other difficulty resulted from the unexpected chymotryptic-like cleavage of some bonds by trypsin. This prevented useful information being obtained for peptide Bb,T-1d, which would have provided an overlap between peptide CB-IV and peptide CB-VIb. $N$-Terminal sequence analysis revealed a major sequence consistent with cleavage of the Tyr-Ala bond at position 55 and a minor sequence from cleavage of an Arg-Tyr bond at position 49 of the $\mathrm{Bb}$ fragment. It also appears that peptide $\mathrm{Bb}, \mathrm{T}$ - $1 \mathrm{~d}$ was shortened at the $C$-terminus as a result of chymotryptic-like activity; the methionine-containing peptide isolated from a V-8 proteinase digest of peptide $\mathrm{Bb}, \mathrm{T}-1 \mathrm{~d}$ was shorter than would have been predicted from the amino acid sequence; also, an additional peptide (T-2) was isolated from the tryptic digest of fragment $\mathrm{Bb}$ with an amino acid composition corresponding to residues $108-120$ of the $\mathrm{Bb}$ fragment, suggesting cleavage at the methionine residue at position 107 .

Despite these problems the tryptic digest at the $\mathrm{Bb}$ fragment enabled the alignment of most of the $\mathrm{CNBr}$-cleavage peptides (Fig. 2).

We adopted a slightly different approach to isolate the peptides required to align the $\mathrm{CNBr}$ cleavage peptides $\mathrm{CB}-\mathrm{IV}$ and $\mathrm{CB}-\mathrm{VIb}$ and to confirm the alignment of peptides $\mathrm{CB}-\mathrm{V}$ and $\mathrm{CB}-\mathrm{VII}-2$. Clostripain cleaves the $\mathrm{Bb}$ fragment to generate an $\mathrm{N}$-terminal fragment $\mathrm{Bb}, \mathrm{Cl}-3$ (mol.wt. approx. 30000) that is resistant to further proteolysis (Christie et al., 1980). This fragment contains 8 methionine and 7 arginine residues, and this is good starting material from which to isolate the remaining peptides. We once again chose to cleave at arginine residues, although in this instance we used clostripain to cleave peptide $\mathrm{Bb}, \mathrm{Cl}-3$ after rendering it susceptible to further proteolysis by complete reduc- tion, alkylation and succinoylation. Succinoylation, as well as disrupting the structure of the $\mathrm{Bb}, \mathrm{Cl}-3$ fragment, was a precaution against any 'nonspecific' cleavage of lysine residues. From results obtained with clostripain it is clear that this enzyme provides a useful alternative to trypsin for argininespecific cleavage of proteins and peptides. It is noteworthy, however, that not all arginine bonds were cleaved: the arginine residue at position 156, which is adjacent to a succinoylated lysine residue, was cleaved in preference to the Arg-Glu bond at position 160 of the $\mathrm{Bb}$ sequence (Fig. 2). The sequence of two clostripain peptides $\mathrm{Bb}, \mathrm{Cl}-3, \mathrm{Cl}-1$ and $\mathrm{Bb}, \mathrm{Cl}-3, \mathrm{Cl}-2$ completed the alignment of the $\mathrm{CNBr}$-cleavage peptides of the $\mathrm{Bb}$ fragment.

As was the case for peptide $\mathrm{Bb}, \mathrm{T}-\mathrm{le}$, it was necessary to sub-digest peptide $\mathrm{Bb}, \mathrm{Cl}-3, \mathrm{Cl}-1$ with $\mathrm{V} 8$ proteinase to isolate methionine-containing peptides. We have relied heavily on the use of h.p.l.c. for peptide separation, and the solvent systems employed in the present work are suitable for the vast majority of peptides containing 3-50 residues.

The sequence of peptide $\mathrm{Bb}, \mathrm{Cl}-3, \mathrm{Cl}-1, \mathrm{SP}-8 / 9$ revealed the presence of an additional methionine residue and a sequence -Ser-Met-Met-Ser- corresponding to positions $105-108$ of the sequence of fragment $\mathrm{Bb}$. The presence of free homoserine as a product of $\mathrm{CNBr}$ cleavage would have been missed during separation of the small peptides by h.p.l.c. (Christie \& Gagnon, 1982). Thus the Bb fragment contains a total of 9 methionine residues. This value is one residue more than that deduced from the amino acid composition of the $\mathrm{Bb}$ fragment, although the result is in agreement with the amino acid composition of Factor $\mathrm{B}$, assuming that the $\mathrm{Ba}$ fragment contains only one methionine residue (Christie \& Gagnon, 1982). The $N$-terminal sequences of the $\mathrm{Ba}$ fragment also shows the presence of a Met-Thr bond at position 128 and the sequence of a peptide not isolated from $\mathrm{CNBr}$ digests of fragment $\mathrm{Bb}$ or Factor $\mathrm{B}$.

Met-Thr bonds and to a smaller extent Met-Ser bonds are resistant to $\mathrm{CNBr}$ cleavage, and in some cases can result in the formation of an internal homoserine residue without chain cleavage (Schroeder et al., 1969). The presence of two such bonds in close proximity probably results in the presence of the partial $\mathrm{CNBr}$-cleavage product CB-III (mol.wt. approx. 20000) from $\mathrm{CNBr}$ digests of fragment $\mathrm{Bb}$ and Factor $\mathrm{B}$, and may account for peptide CB-IV containing $1.3 \mathrm{~mol}$ of homoserine/ mol (Christie \& Gagnon, 1982). However no peptide with the $N$-terminal sequence Hse-Ser-Trp was detected.

The likely sites of carbohydrate attachment through asparagine residues in the $N$-terminal sequence of fragment $\mathrm{Bb}$ are at positions 26 and 119. In both cases the sequence is consistent with the 
Asn-Xaa-Ser or Asn-Xaa-Thr sequence requirement for the $N$-linkage of carbohydrate (Neuberger et al., 1972). Moreover, the glucosamine contents of peptides CB-IV and CB-VIb account for all the glucosamine in the $\mathrm{Bb}$ fragment (Christie \& Gagnon, 1982). With peptide CB-VIb additional evidence is provided from amino acid analysis (Christie \& Gagnon, 1982), which shows the presence of one aspartic acid/asparagine residue additional to those accounted for by sequence analysis. Peptide CB-IV is too large for meaningful conclusions to be drawn from the amino acid composition. It is probable that positions 26 and 119 contain the only carbohydrate present in the $\mathrm{Bb}$ fragment, as the $\mathrm{Bb}$ fragment does not contain $O$-linked carbohydrate, as indicated by absence of galactosamine from the $\mathrm{Bb}$ fragment (Christie \& Gagnon, 1982). The presence of carbohydrate at positions 26 and 119 probably results in the resistance of peptide $\mathrm{Bb}, \mathrm{Cl}-3$ to further degradation by clostripain. It may be noted that one potential site for $N$-linked carbohydrate, the asparagine residue at position 36 of fragment $\mathrm{Bb}$, is unglycosylated.

A free thiol group at position 33 has previously been localized in the $\mathrm{Bb}$ fragment (Christie \& Gagnon, 1982). This residue is located in a portion of the molecule containing carbohydrate-attachment sites and lacking disulphide bonds. It was shown that the cysteine residues at positions 219 and 252 were disulphide-linked to cysteine residues within the $C$-terminal $\mathrm{CB}$-II portion of the $\mathrm{Bb}$ fragment.

The present work, along with the sequence of the major $\mathrm{CNBr}$-cleavage fragment of $\mathrm{Bb}$ in the following paper (Christie \& Gagnon, 1983), provides the complete sequence of the catalytically active $\mathrm{Bb}$ fragment from human complement Factor B.
We are grateful to Prefessor R. R. Porter for his continued help and encouragement. We thank Mr. P. Fisher for technical assistance in the purification of Factor B, and Mr. A. C. Willis and Mr. T. Gascoyne for their assistance in amino acid sequence determination and amino acid analysis. D. L. C. is a Nuffield Dominions Demonstrator.

\section{References}

Christie, D. L. \& Gagnon, J. (1982) Biochem. J. 201, 555-567

Christie, D. L. \& Gagnon, J. (1983) Biochem. J. 209, 61-70

Christie, D. L., Gagnon, J. \& Porter, R. R. (1980) Proc. Natl. Acad. Sci. U.S.A. 77, 4923-4927

Fothergill, J. E. \& Anderson, W. H. K. (1978) Curr. Top. Cell. Regul. 13, 259-311

Kerr, M. A. (1979) Biochem. J. 183, 615-622

Lesavre, P. H., Hugli, T. E., Esser, A. F. \& MüllerEberhard, H. J. (1979) J. Immunol. 123, 529-534

Mole, J. E. \& Niemann, M. A. (1980) J. Biol. Chem. 255 , 8472-8476

Müller-Eberhard, H. J. \& Schreiber, R. D. (1980) $A d v$. Immunol. 29, 1-53

Neuberger, A., Gottschalk, A., Marshall, R. D. \& Spiro, R. G. (1972) in Glycoproteins (Gottschalk, A., ed.), 2nd edn., vol. 5, part A, pp. 450-490, Elsevier, Amsterdam

Niemann, M. A., Volanakis, J. E. \& Mole, J. E. (1980) Biochemistry 19, 1576-1583

Porter, R. R. (1979) in Defence and Recognition IIB (Lennox, E. S., ed.), vol. 23, pp. 177-212, University Park Press, Baltimore

Reid, K. B. M. \& Porter, R. R. (1981) Annu. Rev. Biochem. 50, 433-464

Schroeder, W. A., Shelton, J. B. \& Shelton, J. R. (1969) Arch. Biochem. Biophys. 130, 551-556

World Health Organisation (1968) Bull. W. H. O. 39, 935-936 